\title{
SYNTHESIS AND CHARACTERIZATION OF GAMMA ALUMINA AND ITS ADSORPTION CAPABILITY TEST FOR POMALAA MAGNESIUM LATERITE, SOUTHEAST SULAWESI
}

\author{
SINTESIS DAN KARAKTERISASI GAMA ALUMINA SERTA \\ PENGUJIAN KEMAMPUAN ADSORPSINYA PADA MAGNESIUM \\ LATERIT ASAL POMALAA, SULAWESI TENGGARA
}

\author{
TITIN S. FATIMAH ${ }^{1,2}$, ATIEK R. NOVIYANTI ${ }^{2}$, JULIANDRI ${ }^{2}$ and SOLIHUDIN ${ }^{2}$ \\ ${ }^{1}$ R\&D Center for Mineral and Coal Technology \\ Jalan Jenderal Sudirman 623 Bandung \\ Phone. (+6222) 6030483. Fax. (+6222) 6003373 \\ e-mail: tisif.tsf@gmail.com \\ ${ }^{2}$ Department of Chemistry, Faculty of Mathematics \& Natural Science, Padjadjaran University \\ Jalan Raya Bandung Sumedang Km. 21 \\ Phone/Fax. (+6222) 7794391
}

\begin{abstract}
Based on variations in calcination temperature, gamma alumina has successfully been made using a simple sol-gel method for Pomalaa magnesium-laterite adsorption from the South East of Sulawesi. The laterite leached by sulfuric acid was then precipitated by ammonia, to make the magnesium was separated from its main impurities ( $\mathrm{Si}$, Fe and $\mathrm{Al}$ ). Temperature variations at $500,650,800$ and $950{ }^{\circ} \mathrm{C}$ in gamma alumina making formed the gamma alumina phase while the alpha alumina phase was formed at $1100^{\circ} \mathrm{C}$. The higher calcination temperature the lower the specific surface area respectively from 196.385, 156.239, 105.725, 96.134 and $15.396\left(\mathrm{~m}^{2} / \mathrm{g}\right)$. This results in decreasing the magnesium of the laterite $9.04,8.70,8.09,6.39$ and $0.29(\mathrm{mg} / \mathrm{L})$ respectively. The $800{ }^{\circ} \mathrm{C}$-calcination gamma alumina has the highest volume of the pore, namely $0.3265 \mathrm{~mL} / \mathrm{g}$ and the radius of $61.76 \AA$. The gamma alumina isotherm curve is type IV. The SEM-EDS test shows an aggregation spherical shape. Gamma alumina was detected to adsorb Mg laterite. The X-ray mapping of SEM-EDS test shows even distribution between gamma alumina, magnesium, and nickel. The highest adsorption is retained by GA-800/3 sample, namely $81.31 \%$.
\end{abstract}

Keywords: adsorption, gamma alumina, leaching, isotherm, sol-gel

\begin{abstract}
ABSTRAK
Berdasarkan variasi suhu kalsinasi, gama alumina telah berhasil dibuat dengan metode sol-gel sederhana untuk adsorpsi magnesium laterit Pomalaa, Sulawesi Tenggara. Laterit dilindi menggunakan asam sulfat kemudian diendapkan dengan amonia untuk memisahkan magnesium dari pengotor utama (Si, Fe dan Al). Pada variasi suhu kalsinasi 500, 650, 800 dan $950{ }^{\circ} \mathrm{C}$ terbentuk fase gamma alumina sedangkan pada $1100{ }^{\circ} \mathrm{C}$ terbentuk fase alfa alumina. Semakin naik suhu kalsinasi, semakin menurun luas permukaan spesifik, berturut-turut 196,385; 156,239; 105,725; 96,134 dan $15,396\left(\mathrm{~m}^{2} / \mathrm{g}\right)$. Hal ini mengakibatkan menurunnya kapasitas adsorpsi magnesium berasal dari laterit berturut-turut 9,04; 8,70; 8,09; 6,39 dan 0,29 (mg/L). Gamma alumina pada kalsinasi $800{ }^{\circ} \mathrm{C}$ memiliki volume dan radius pori paling besar yaitu $0,3265 \mathrm{~mL} / \mathrm{g}$ dan $61,76 \AA$. Kurva isotermal gamma alumina termasuk ke dalam tipe IV. Hasil pengujian SEM menunjukkan bentuk agregasi partikel berbentuk bola. Gamma alumina terdeteksi telah mengadsorpsi $\mathrm{Mg}$ dari laterit. Hasil X-ray mapping menunjukkan sebaran yang merata antara gamma alumina, magnesium dan nikel. Percontoh GA800/3 memiliki adsorpsi Mg terbesar yaitu 81,31\%.
\end{abstract}

Kata kunci: adsorpsi, gamma alumina, pelindian, isotermal dan sol-gel 


\section{INTRODUCTION}

Gamma alumina $\left(\mathrm{y}-\mathrm{Al}_{2} \mathrm{O}_{3}\right)$ is an alumina transition that is formed from an amorphous or boehmite precursor. It performs a large surface area and porosity. The material is stable at $1100^{\circ} \mathrm{C}$ (Harfani, 2009). It is widely used as adsorbents, a catalyst or catalyst support in the automotive and petroleum industries, structural composites in spacecraft, abrasive and thermal wear coatings (Paglia et al., 2004). As a catalyst or catalyst support, it is widely used in several chemical processes, such as ammonia synthesis, synthesis gas, and hydrogen production, oil hydrogenation, petroleum refining, automotive emissions control, among others (Adans et al., 2016).

Gamma alumina as an adsorbent has been studied widely, including adsorbent for dyes Orange-G (Banerjee et al., 2017), adsorbent for nitrate from aqueous solution (Bhatnagar, Kumar and Sillanpää, 2010), adsorbent for defluoridation of water (Chinnakoti et al., 2017) and adsorbent $\mathrm{Cr}^{6+}, \mathrm{Ni}^{2+}, \mathrm{Cd}^{2+}$ and $\mathrm{Pb}^{2+}$ (Poursani et al., 2015).

There are several methods to prepare gamma aluminas such as mechanical synthesis, vapor phase reaction, precipitation, combustion, and sol-gel methods (Shayesteh et al., 2013). Márquez-Alvarez et al. (2008) used surfactant for preparing gamma alumina using a sol-gel method. Mahmoudi et al. (2012) and Adans et al. (2016) made gamma alumina from aluminum chloride under acid conditions by a sol-gel method.

Nickel laterites account for $40 \%$ of global nickel supply. The materials serve as an important product of mining material. The laterites occurred due to chemical weathering from the olivine-rich ultramafic rocks such as dunite, peridotite, chromatite and secondarily altered to serpentine-serpentinized. The majority of magnesium silicate contains about $0.3 \% \mathrm{Ni}$. Olivine or $(\mathrm{Mg}, \mathrm{Fe})_{2} \mathrm{SiO}_{4}$, is an unstable mineral occurred during the weathering process. The process has occurred for million years when the ultramafic rocks were exposed into the surface. The chemical weathering caused the elements with low-to-immobile such as $\mathrm{Ni}, \mathrm{Fe}$, and $\mathrm{Co}$ has undergone enrichment in a residual or secondary, which is called laterization processes. In the world, the ore producing countries are New Caledonia, Cuba,
Philippines, Indonesia, Columbia, and Australia. Table 1 showed the minerals in $\mathrm{Ni}$ laterite deposits (Butt and Cluzel, 2013).

Leaching the Yuanjiang laterite from China by sulphuric acid has been studied by Liu, Chen and $\mathrm{Hu}$ (2009). The result shows that the solubility of the laterite minerals in sulphuric acid decrease as follows lizardite $>$ goethite $>$ maghemite $>$ magnetite $\approx$ hematite $>$ chromite. The study by Luo et al. (2010) suggests that sulphuric acid dissolved the saprolitic laterite materials consists mainly of nickel-substituted lizardite. The results showed that the activation energies were $53.9 \mathrm{KJmol}^{-1}$ and $59.4 \mathrm{KJmol}^{-1}$ for nickel and magnesium respectively. The similarity activation energies of nickel and magnesium leaching from the saprolitic laterite material by sulphuric acid mean that the nickel in lizardite occurred simultaneously with the magnesium without complete decomposition of the silicate. This study investigated the dissolution magnesium from Pomalaa laterite by sulphuric acid leaching.

Study of adsorption laterite-based magnesium using gamma alumina never had been conducted before. Laterite-based magnesium contains a high grade. An example of this type is the Pomalaa laterite from the South East Sulawesi that contains $20 \% \mathrm{MgO}$ (Dahlan et al., 2007). The upper magnesium oxides have the $\mathrm{MgO}$ contents of about $20 \%$. Its function as a fertilizer is ineffective because the elemental impurities in laterites such as nickel, cobalt, chrome and other elements cause difficulties to separate them economically and will be harmful to plants and the environment.

The values of $\mathrm{pH}_{\mathrm{pzc}}$ and $\mathrm{pH}_{\text {iep }}$ for various aluminum oxides and hydroxides as well as related materials, reported in the literature, vary widely namely from 5 to 9.6 (Gulicovski, Čerović and Milonjić, 2008). The $\mathrm{pH}_{\mathrm{pzc}}$ of an adsorbent is an important characteristic in determining the $\mathrm{pH}$ value at which the surface of the adsorbent becomes electrically neutral. At $\mathrm{pH}<\mathrm{pHzpc}$ the surface charge is positive, favoring anion adsorption. At $\mathrm{pH}>\mathrm{pHzpc}$ the superficial charge is negative, favoring cation adsorption (Banerjee et al., 2017). For this study, the magnesium was prepared for adsorption by gamma alumina at $\mathrm{pH}=10$. The aim of this study is to examine the synthesis and characterization of gamma alumina and its adsorption capability for magnesium. 
Table 1. Minerals in Ni-laterite deposits (Butt and Cluzel, 2013)

\begin{tabular}{|c|c|c|c|}
\hline \multicolumn{4}{|c|}{ Oxide Ore } \\
\hline Goethite & Oxide & $\alpha-\left(\mathrm{Fe}^{3+}\right) \mathrm{O}(\mathrm{OH})$ & $2 \% \mathrm{Ni}, 0.2 \% \mathrm{Co}$ \\
\hline Asbolane & Oxide & $\left(\mathrm{Ni}^{2+}, \mathrm{Co}^{3+}\right)_{x} \mathrm{Mn}^{4+}(\mathrm{O}, \mathrm{OH})_{4} \cdot \mathrm{nH}_{2} \mathrm{O}$ & $16 \% \mathrm{Ni},>4 \%$ Co \\
\hline Lithiophorite & Oxide & $(\mathrm{Al}, \mathrm{Li}) \mathrm{Mn}^{4+} \mathrm{O}_{2}(\mathrm{OH})_{2}$ & $1 \% \mathrm{Ni}, \sim 7 \% \mathrm{Co}$ \\
\hline \multicolumn{4}{|c|}{ Hydrous Mg Silicate Ore } \\
\hline Ni lizardite - népouite & Serpentine & $\left(\mathrm{Mg}, \mathrm{Ni}_{3} \mathrm{Si}_{2} \mathrm{O}_{5}(\mathrm{OH})_{4}\right.$ & $6-33 \% \mathrm{Ni}$ \\
\hline $7 \AA ̊$ garnierite & Serpentine & Variable, poorly defined & $15 \% \mathrm{Ni}$ \\
\hline Nimite & Chlorite & $\left(\mathrm{Ni}_{5} \mathrm{Al}\right)\left(\mathrm{Si}_{3} \mathrm{Al}\right) \mathrm{O}_{10}(\mathrm{OH})_{8}$ & $17 \% \mathrm{Ni}$ \\
\hline 14Å garnierite & Chlorite & Variable, poorly defined & $3 \% \mathrm{Ni}$ \\
\hline Falcondoite & Sepiolite & $(\mathrm{Ni}, \mathrm{Mg})_{4} \mathrm{Si}_{6} \mathrm{O}_{15}(\mathrm{OH})_{2} \cdot 6 \mathrm{H}_{2} \mathrm{O}$ & $24 \% \mathrm{Ni}$ \\
\hline Kerolite-willemseite & Talc & $(\mathrm{Ni}, \mathrm{Mg})_{3} \mathrm{Si}_{4} \mathrm{O}_{10}(\mathrm{OH})_{2}$ & $16-27 \% \mathrm{Ni}$ \\
\hline $10 \AA$ garnierite & Talc & Variable, poorly defined & $20 \% \mathrm{Ni}$ \\
\hline \multicolumn{4}{|c|}{ Clay Silicate Ore } \\
\hline Nontronite & Smectite & $\mathrm{Na}_{0.3} \mathrm{Fe}_{2}{ }^{3+}(\mathrm{Si}, \mathrm{Al})_{4} \mathrm{O}_{10}(\mathrm{OH})_{2} \cdot \mathrm{nH}_{2} \mathrm{O}$ & $\sim 4 \% \mathrm{Ni}$ \\
\hline Saponite & Smectite & $\left(\mathrm{OH}_{2}\right) \cdot 4 \mathrm{H}_{2} \mathrm{O}$ & $\sim 3 \% \mathrm{Ni}$ \\
\hline
\end{tabular}

\section{METHODOLOGY}

\section{Characterization and Leaching Sulphuric Acid of Laterite-Based Magnesium}

Several companies in Indonesia have processed limonite and saprolite using hydrometallurgy and pyrometallurgy processes to produce $\mathrm{NiO}$, NiS, Ni-matte, and $\mathrm{Fe}-\mathrm{Ni}$ (Prasetyo, 2016). The laterite samples for the experiments were taken from Pomalaa, South East of Sulawesi. The $-100+150$ mesh samples were dried in the oven at $110{ }^{\circ} \mathrm{C}$ for 3 hours to be leached by sulphuric acid $1: 1$ at $150{ }^{\circ} \mathrm{C}$ for 10 hours. The sample was then reacted with the excessive ammonium hydroxide 1:1, filtered to separate the filtrate from its precipitate.

\section{Synthesizing the Gamma Alumina by Sol- Gel Methods}

Poly aluminum chloride (PAC) as the precursor was reacted with ammonium hydroxide under an acid condition to get the precipitate aluminum hydroxide $\left(\mathrm{Al}(\mathrm{OH})_{3}\right)$. The precipitate was then calcined in a tube furnace with various temperatures at 500 , $650,800,950$ and $1100{ }^{\circ} \mathrm{C}$ to get the alumina $\left(\mathrm{Al}_{2} \mathrm{O}_{3}\right)$. The samples of the alumina were milled using a ring mill RS 200 at speed of $700 \mathrm{rpm}$ for 2 minutes. The used samples were coded as GA-500, GA-650, GA-800, GA-950, and GA-1100.

\section{Magnesium Adsorption by Gamma Alumina}

Each of laterite filtrate $(\mathrm{pH}=10)$ was pipetted around $50 \mathrm{~mL}$ and added $5 \mathrm{~g}$ calcined alumina of GA-500, GA-650, GA-800, GA950 , and GA-1100 respectively. They were stirred for 3 hours. The calcined alumina after the adsorption process was separated from the filtrate at $\mathrm{pH} 10$ to be analyzed by SEM while the filtrates were used for AAS tests. The filtrate at a concentration of $\mathrm{pH}=10$, after adsorption from SSA measurements, is the concentration of the elements that was not adsorbed by the gamma alumina.

\section{RESULTS AND DISCUSSION}

\section{Magnesium Characteristics after Sulphuric Acid Leaching}

Initial laterite characterization using $X$-ray diffractometer (XRD) is to identify the mineral type while the atomic absorption spectrophotometer (AAS) identifies the chemical composition of the laterite. The XRD results (Figure 1) show seven types of minerals, namely lizardite $(\mathrm{Mg}, \mathrm{Al})_{3}\left[(\mathrm{Si}, \mathrm{Fe})_{2} \mathrm{O}_{5}\right](\mathrm{OH})_{4} ; \quad$ nontronite $\left(\mathrm{Na}_{0,3} \mathrm{Fe}_{2} \mathrm{Si}_{4} \mathrm{O}_{10}(\mathrm{OH})_{2} \cdot 4 \mathrm{H}_{2} \mathrm{O}\right.$; quartz $\left(\mathrm{SiO}_{2}\right)$; enstatite $\left(\mathrm{MgSiO}_{3}\right) ;$ hematite $\left(\mathrm{Fe}_{2} \mathrm{O}_{3}\right)$; forsterite $\left(\mathrm{Mg}_{2} \mathrm{SiO}_{4}\right)$ and chlorite-serpentine $(\mathrm{Mg}, \mathrm{Al})_{6}\left(\mathrm{Si}, \mathrm{Al}_{4} \mathrm{O}_{10}(\mathrm{OH})_{8}\right.$.

From the AAS tests in which the laterite was melted by sodium peroxide, the major chemical compositions are $\mathrm{SiO}_{2}, \mathrm{MgO}, \mathrm{Fe}_{2} \mathrm{O}_{3}$, $\mathrm{Cr}_{2} \mathrm{O}_{3}$, and Ni. The chemical composition of the laterite is presented in Table 2.

The AAS results confirm that the $\mathrm{MgO}$, $\mathrm{Fe}_{2} \mathrm{O}_{3}, \mathrm{Al}_{2} \mathrm{O}_{3}$, and $\mathrm{Ni}$ dissolved in sulfuric acid, while $\mathrm{Cr}_{2} \mathrm{O}_{3}$ dissolved slightly and $\mathrm{SiO}_{2}$ did not dissolve at all but formed a white solid 
of $\mathrm{SiO}_{2}$. The AAS data from laterite leaching by sulfuric acid are shown in Table 3 .

Table 2. Chemical composition of laterite detected by AAS

\begin{tabular}{clc}
\hline No. & Element/oxide & Concentration (\%) \\
\hline 1. & $\mathrm{Ni}$ & 1.44 \\
2. & $\mathrm{SiO}_{2}$ & 37.41 \\
3. & $\mathrm{MgO}$ & 24.13 \\
4. & $\mathrm{Fe}_{2} \mathrm{O}_{3}$ & 16.17 \\
5. & $\mathrm{Cr}_{2} \mathrm{O}_{3}$ & 5.35 \\
6. & $\mathrm{Al}_{2} \mathrm{O}_{3}$ & 2.01 \\
7. & $\mathrm{CaO}$ & 0.278 \\
8. & $\mathrm{MnO}$ & 0.187 \\
9. & $\mathrm{K}_{2} \mathrm{O}$ & 0.005 \\
10. & $\mathrm{Na}_{2} \mathrm{O}$ & 0.025 \\
11. & $\mathrm{LOI}$ & 12.45 \\
\hline
\end{tabular}

Table 3. Chemical composition of laterite after leaching by sulphuric acid

\begin{tabular}{clc}
\hline No. & Element/oxide & Concentration (\%) \\
\hline 1. & $\mathrm{Ni}$ & 1.44 \\
2. & $\mathrm{SiO}_{2}$ & - \\
3. & $\mathrm{MgO}$ & 24.35 \\
4. & $\mathrm{Fe}_{2} \mathrm{O}_{3}$ & 16.03 \\
5. & $\mathrm{Cr}_{2} \mathrm{O}_{3}$ & 0.266 \\
6. & $\mathrm{Al}_{2} \mathrm{O}_{3}$ & 2.02 \\
7. & $\mathrm{CaO}$ & 0.286 \\
8. & $\mathrm{MnO}$ & 0.191 \\
9. & $\mathrm{K}_{2} \mathrm{O}$ & 0.005 \\
10. & $\mathrm{Na}_{2} \mathrm{O}$ & 0.024 \\
\hline
\end{tabular}
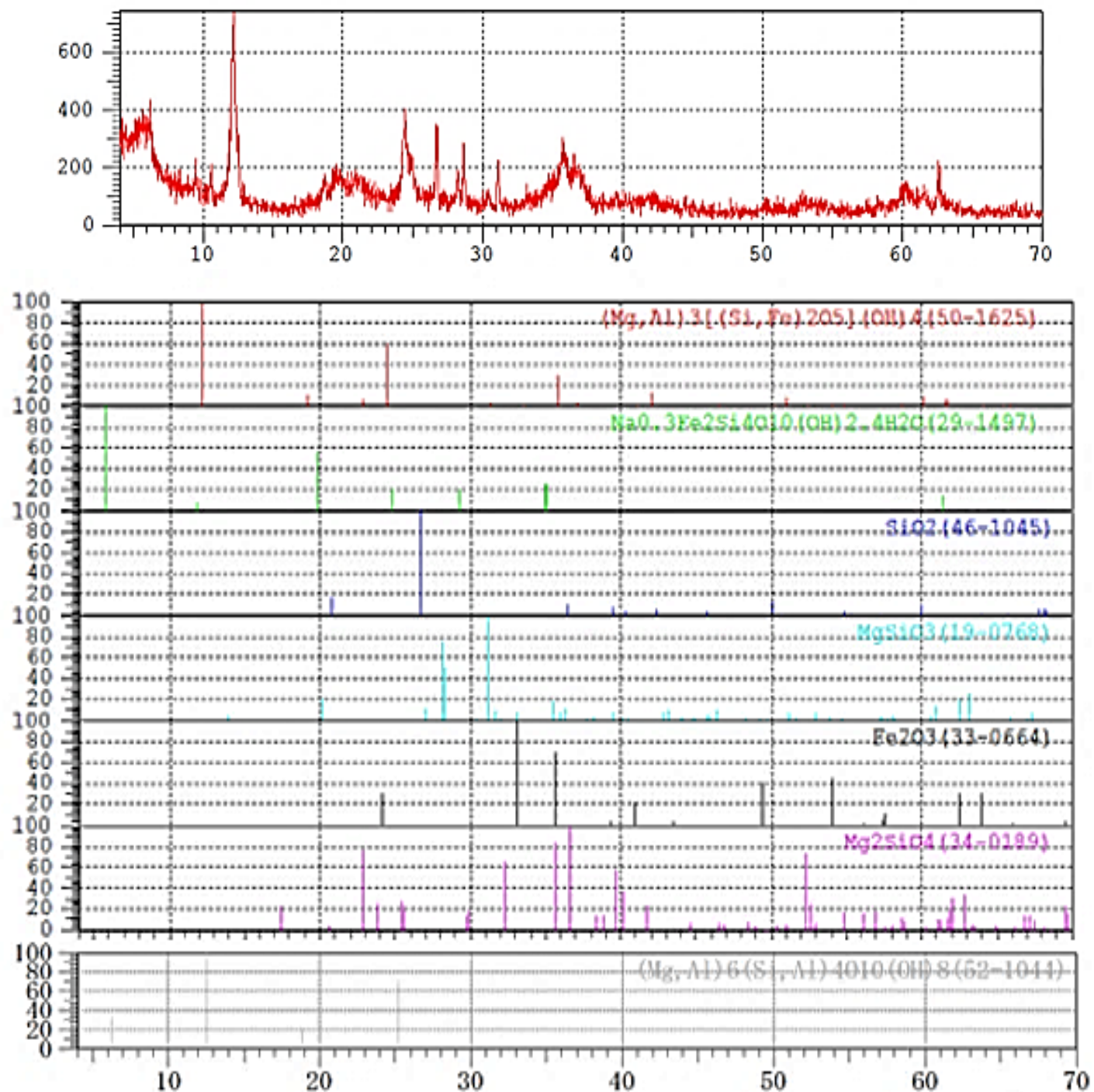

Figure 1. XRD analysis of laterite 
This study focuses on magnesium element. It is necessary to separate it from other elements, especially the $\mathrm{Fe}$ and $\mathrm{Al}$ elements which have a considerable large concentration. The separation was carried out by adding the excessive ammonia solution to the solution from sulfuric acid leaching. The results were a solid residue and a filtrate. Those were separated through a filtering process. The filtrate was then analyzed by AAS. Table 4 illustrates the results. Fe and Al were not detected in the filtrate at $\mathrm{pH}=10$ when such a filtrate was reacted with ammonia solution. The iron (III) formed a red brown solid, namely gelatin of iron (III) hydroxide. Referring to the aluminum, the element formed a white gelatin of aluminum (III) hydroxide. Thus the filtrate at $\mathrm{pH}=10$ was free from the $\mathrm{Fe}$ and $\mathrm{Al}$ impurities. The reactions are as follows:

$$
\begin{gathered}
\mathrm{Fe}^{3+}{ }_{(\mathrm{aq})}+3 \mathrm{NH}_{3(\mathrm{aq})}+3 \mathrm{H}_{2} \mathrm{O}_{(\mathrm{ll})} \\
3 \mathrm{NH}_{4}^{+}{ }_{(\mathrm{aq})} \mathrm{Fe}(\mathrm{OH})_{3(\mathrm{~s})} \downarrow+ \\
\mathrm{Al}^{3+}{ }_{(\mathrm{aq})}+3 \mathrm{NH}_{3(\mathrm{aq})}+3 \mathrm{H}_{2} \mathrm{O}_{(\mathrm{l})}
\end{gathered}
$$

Table 4. Composition of the filtrate $\mathrm{pH}=10$

\begin{tabular}{clc}
\hline No. & Element/oxide & Concentration (\%) \\
\hline 1 & $\mathrm{Ni}$ & 1.42 \\
2 & $\mathrm{MgO}$ & 23.81 \\
3 & $\mathrm{Fe}_{2} \mathrm{O}_{3}$ & - \\
4 & $\mathrm{Cr}_{2} \mathrm{O}_{3}$ & - \\
5 & $\mathrm{Al}_{2} \mathrm{O}_{3}$ & - \\
6 & $\mathrm{CaO}$ & 0.277 \\
7 & $\mathrm{MnO}$ & 0.191 \\
8 & $\mathrm{~K}_{2} \mathrm{O}$ & 0.005 \\
9 & $\mathrm{Na}_{2} \mathrm{O}$ & 0.023 \\
\hline
\end{tabular}

The filtrate at $\mathrm{pH}=10$ retains relatively large amounts of the elements including magnesium and nickel. The addition of excess ammonia to the leached laterite by sulphuric acid will not be able to precipitate magnesium and nickel as the nickel will form a complex solution of hexamine nickel (II) or $\left[\mathrm{Ni}\left(\mathrm{NH}_{3}\right)_{6}\right]^{2+}$ which has a dark blue color while the magnesium with excess ammonia results in reducing hydroxyl concentration due to the common ion effect. As a result, the small concentration of hydroxyl ion continues to decrease and the results of the magnesium salt remain in the form solution (salting-out effect).

\section{Synthesizing the Gamma Alumina}

Gamma alumina in this study was made from poly-aluminum chloride using a sol-gel method with the addition of ammonia solution until $\mathrm{pH}$ 5.5. The produced aluminum hydroxide solid was calcined at variation temperatures of 500 , $650,800,950$ and, $1100{ }^{\circ} \mathrm{C}$. The sol-gel method is very simple and produces pure Al $(\mathrm{OH})_{3}$ because the ammonium chloride as a by-product will be lost during the calcination process to be $\mathrm{NH}_{3}$ and $\mathrm{HCl}$. The material safety data sheet (MSDS) of the ammonium chloride from Science Laboratory states that the decomposition temperature of ammonium chloride is $338{ }^{\circ} \mathrm{C}$, it means that during the calcination at $500{ }^{\circ} \mathrm{C}$, the ammonium chloride should be removed to obtain pure alumina. The produced gamma alumina purity can be seen in Figure 7. The spot analysis of the SEM-EDS test did not find any $\mathrm{NH}_{3}$ or $\mathrm{Cl}$. The SEM mapping data in Figure 10 also show that there are no $\mathrm{NH}_{3}$ or $\mathrm{Cl}$ impurities, only Al, $\mathrm{Mg}, \mathrm{Ni}$ and $\mathrm{O}$. The reaction is as follows:

$$
\begin{aligned}
\mathrm{AlCl}_{3(\mathrm{l})}+3 \mathrm{NH}_{4} \mathrm{OH}_{(\mathrm{l})} & \rightarrow \mathrm{Al}(\mathrm{OH})_{3(\mathrm{~s})} \downarrow+3 \mathrm{NH}_{4} \mathrm{Cl}_{(\mathrm{l})} \\
\mathrm{NH}_{4} \mathrm{Cl}_{(\mathrm{l})} & \rightarrow \mathrm{NH}_{3(\mathrm{~g})}+\mathrm{HCl}_{(\mathrm{g})}
\end{aligned}
$$

\section{Characterization of Gamma Alumina}

Calcined alumina was milled using a ring mill at $700 \mathrm{rpm}$ for 2 minutes. The obtained alumina powder was analyzed for its particle size using an LS Particle Size Analyzer. The data show that the largest size within the sample was $111.0 \mu \mathrm{m}$. The alumina was then characterized using an XRD to determine whether the gamma alumina is in metastable or other phases. The results are shown in Figure 2. It shows that at 500,650, 800 and $950{ }^{\circ} \mathrm{C}$, the formation of gamma alumina (metastable alumina) has broad peaks and $2 \theta$ values are around $37^{\circ}, 46^{\circ}$, and $67^{\circ}$, while at temperature of $1100^{\circ} \mathrm{C}$, the alumina crystalline phase forms a sharp peak (stable alpha alumina phase).

The XRD refinement was conducted using a HighScore Plus program, a standard to fit the sample. From the XRD data, it is known that GA-500 up to GA-900 is gamma aluminas. The data corresponded with the ICSD 98-0066559 while the GA-1100 sample is the alpha alumina that corresponds with the ICSD 98007-5559. The alumina and standard sample data are shown in Table 5. Based on Table 5, the results of refinement using the HighScore Plus program show that the GA-500 to GA900 is gamma alumina. Those represent a cubic crystal system with an $\mathrm{Fd}-3 m$ space group, and typical intensities at $2 \theta$ from the Miller indices of 044, 004, 113 and 022 
respectively. The GA-1100 sample is an alpha alumina that has a hexagonal crystal.

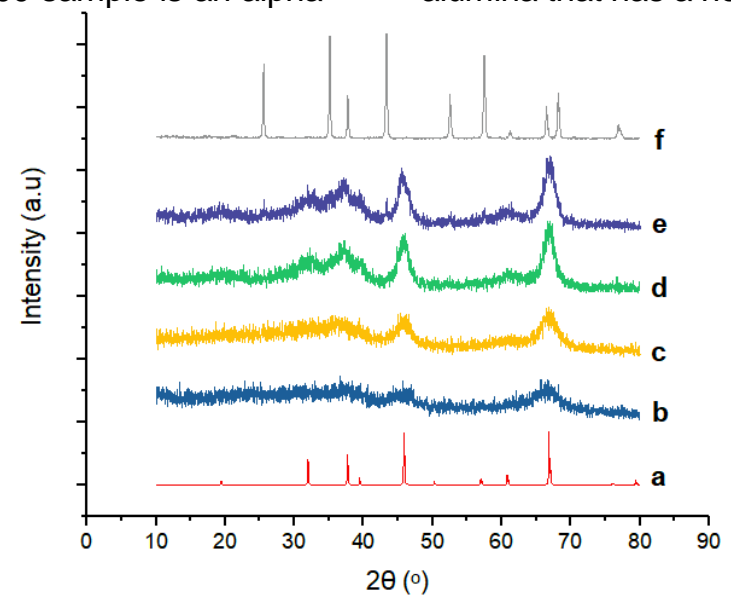

Figure 2. Result of XRD test on calcined gamma alumina at various calcination temperatures (a) standard gamma alumina ICSD \# 66559 (b) $500{ }^{\circ} \mathrm{C}$; (c) $650{ }^{\circ} \mathrm{C}$;

(d) $800{ }^{\circ} \mathrm{C}$; (e) $950^{\circ} \mathrm{C}$ and (f) $1100{ }^{\circ} \mathrm{C}$, particle size $111.0 \mu \mathrm{m}$

Table 5. Aluminas sample and its standard from the HighScore Plus

\begin{tabular}{|c|c|c|c|c|c|c|c|c|}
\hline \multirow[b]{2}{*}{ Sample } & \multirow{2}{*}{$\begin{array}{l}\text { Compound/ } \\
\text { GOF }\end{array}$} & \multirow{2}{*}{$\begin{array}{l}\text { Crystal } \\
\text { system }\end{array}$} & \multirow[b]{2}{*}{$\begin{array}{l}2 \theta \\
(\circ)\end{array}$} & \multirow[b]{2}{*}{$\mathrm{I} / \mathrm{I} 1$ (\%) } & \multirow{2}{*}{$\begin{array}{c}\text { Indices } \\
\text { Miller (hkl) }\end{array}$} & \multirow{2}{*}{$\begin{array}{l}\text { Space } \\
\text { group }\end{array}$} & \multicolumn{2}{|c|}{ Lattice parameter } \\
\hline & & & & & & & $\begin{array}{c}a=b=c \\
(\AA)\end{array}$ & $\begin{array}{c}\alpha=\beta=\gamma \\
\left({ }^{\circ}\right)\end{array}$ \\
\hline $\begin{array}{l}\text { Standard } \\
\text { ICSD 98- } \\
006-6559\end{array}$ & $\begin{array}{l}\text { Gamma } \\
\text { alumina }\end{array}$ & Cubic & $\begin{array}{l}31.97 \\
37.68 \\
45.85 \\
66.85 \\
\end{array}$ & $\begin{array}{l}48.80 \\
57.40 \\
88.00 \\
100.0 \\
\end{array}$ & $\begin{array}{l}022 \\
113 \\
004 \\
044 \\
\end{array}$ & Fd-3m & $\begin{array}{c}a=b=c \\
7.91\end{array}$ & $\begin{array}{c}\alpha=\beta=\gamma \\
90\end{array}$ \\
\hline $500-G A$ & $\begin{array}{c}\text { Gamma } \\
\text { alumina/ } \\
\text { GOF=0.94 }\end{array}$ & Cubic & $\begin{array}{l}32.15 \\
37.85 \\
46.00 \\
66.97\end{array}$ & $\begin{array}{l}48.70 \\
57.30 \\
88.00 \\
100.0\end{array}$ & $\begin{array}{l}022 \\
113 \\
004 \\
044\end{array}$ & Fd-3m & $\begin{array}{c}a=b=c \\
7.92\end{array}$ & $\begin{array}{c}\alpha=\beta=\gamma \\
90\end{array}$ \\
\hline $650-G A$ & $\begin{array}{c}\text { Gamma } \\
\text { alumina/ } \\
\text { GOF }=1.19\end{array}$ & Cubic & $\begin{array}{l}31.47 \\
37.23 \\
45.48 \\
66.73 \\
\end{array}$ & $\begin{array}{l}49.32 \\
57.98 \\
88.26 \\
100.0 \\
\end{array}$ & $\begin{array}{l}022 \\
113 \\
004 \\
044 \\
\end{array}$ & Fd-3m & $\begin{array}{c}a=b=c \\
7.80\end{array}$ & $\begin{array}{c}\alpha=\beta=\gamma \\
90\end{array}$ \\
\hline $800-G A$ & $\begin{array}{c}\text { Gamma } \\
\text { alumina/ } \\
\text { GOF }=1.70\end{array}$ & Cubic & $\begin{array}{l}31.39 \\
37.17 \\
45.45 \\
66.80 \\
\end{array}$ & $\begin{array}{l}49.50 \\
58.19 \\
88.35 \\
100.0 \\
\end{array}$ & $\begin{array}{l}022 \\
113 \\
004 \\
044 \\
\end{array}$ & Fd-3m & $\begin{array}{c}a=b=c \\
7.81\end{array}$ & $\begin{array}{c}\alpha=\beta=\gamma \\
90\end{array}$ \\
\hline $950-\mathrm{GA}$ & $\begin{array}{c}\text { Gamma } \\
\text { alumina/ } \\
\text { GOF }=1.82\end{array}$ & Cubic & $\begin{array}{l}31.39 \\
37.18 \\
45.46 \\
66.81 \\
\end{array}$ & $\begin{array}{l}49.53 \\
58.22 \\
88.36 \\
100.0 \\
\end{array}$ & $\begin{array}{l}022 \\
113 \\
004 \\
044\end{array}$ & Fd-3m & $\begin{array}{c}a=b=c \\
7.81\end{array}$ & $\begin{array}{c}\alpha=\beta=\gamma \\
90\end{array}$ \\
\hline $\begin{array}{l}\text { Standard } \\
\text { ICSD 98- } \\
007-5559\end{array}$ & Alfa alumina & Hexagonal & $\begin{array}{l}25.58 \\
35.15 \\
37.78 \\
43.35 \\
52.55 \\
57.50 \\
66.52 \\
68.21\end{array}$ & $\begin{array}{l}66.20 \\
97.00 \\
45.50 \\
97.90 \\
50.20 \\
100.0 \\
40.00 \\
30.80\end{array}$ & $\begin{array}{l}012 \\
104 \\
110 \\
113 \\
024 \\
116 \\
214 \\
030\end{array}$ & $\mathrm{R}-3 \mathrm{C}$ & $\begin{array}{c}a=b=4.76 \\
c=12.99\end{array}$ & $\begin{array}{c}\alpha=\beta=90 \\
\gamma=120\end{array}$ \\
\hline $1100-G A$ & $\begin{array}{l}\text { Alfa alumina/ } \\
\text { GOF }=1.71\end{array}$ & Hexagonal & $\begin{array}{l}25.52 \\
35.09 \\
37.72 \\
43.26 \\
52.50 \\
57.45 \\
66.46\end{array}$ & $\begin{array}{l}61.23 \\
97.06 \\
45.49 \\
97.87 \\
50.16 \\
100.0 \\
39.96\end{array}$ & $\begin{array}{l}012 \\
104 \\
110 \\
113 \\
024 \\
116 \\
214\end{array}$ & $\mathrm{R}-3 \mathrm{C}$ & $\begin{array}{c}a=b=4.76 \\
c=12.99\end{array}$ & $\begin{array}{c}\alpha=\beta=90 \\
y=120\end{array}$ \\
\hline
\end{tabular}



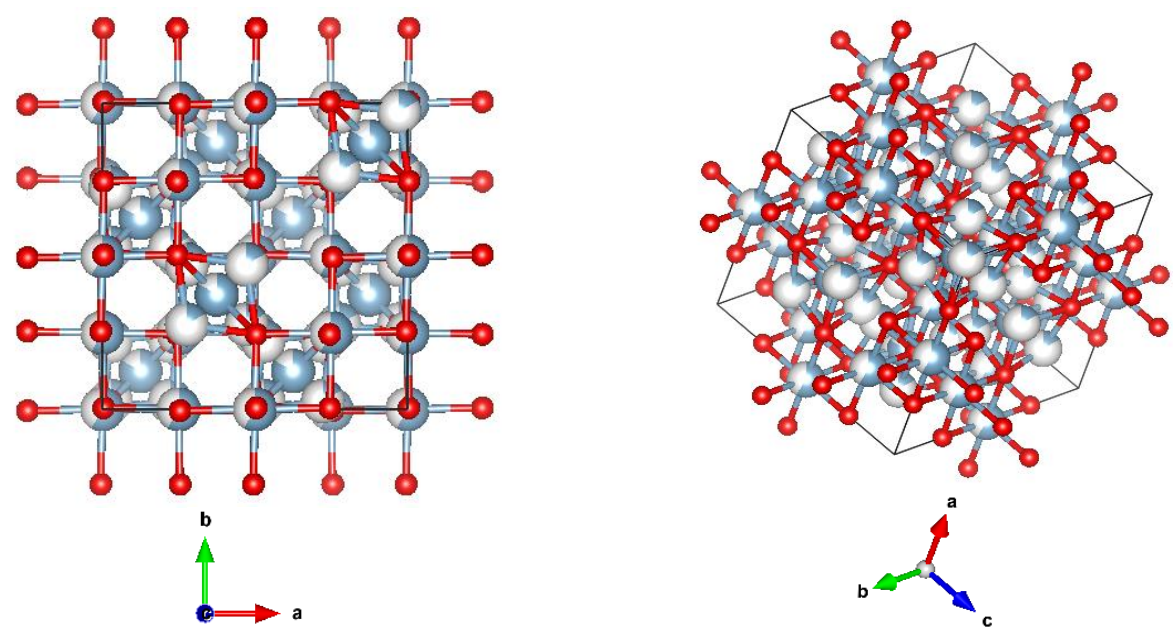

(a)
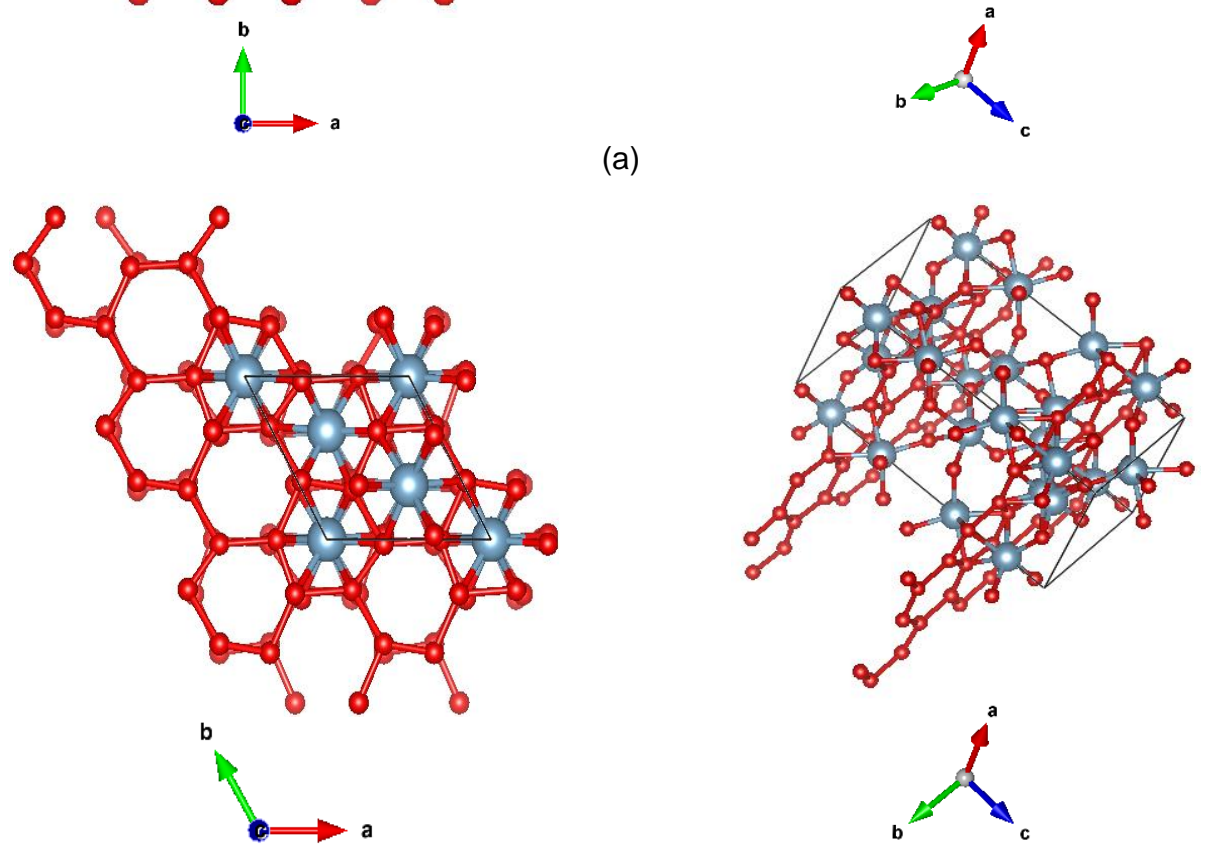

(b)

Figure 3. Three-dimensional structure by fitting the HighScore Plus Program (a) gamma alumina; (b) alfa alumina

The isotherm curve of the nitrogen adsorption-desorption that depicted the nitrogen adsorption amount isotherm curve of the nitrogen adsorption-desorption against the relative pressure $P / P_{0}$ is shown in Figure 4. This isotherm belongs to the isotherm type IV, which is an adsorption type of mesoporous solids. The presence of pores on the surface of the solid will have an effect on limiting the layer number of the adsorbate and capillary condensation phenomena which causes hysteresis (Adamson, 1990). In Figure 4, the red line represents the adsorption process and the blue one represents the desorption process. The greatest loop hysteresis occurs on GA500 . The amount of adsorbate that lost from the pore during the desorption process shows the total volume of pore. 


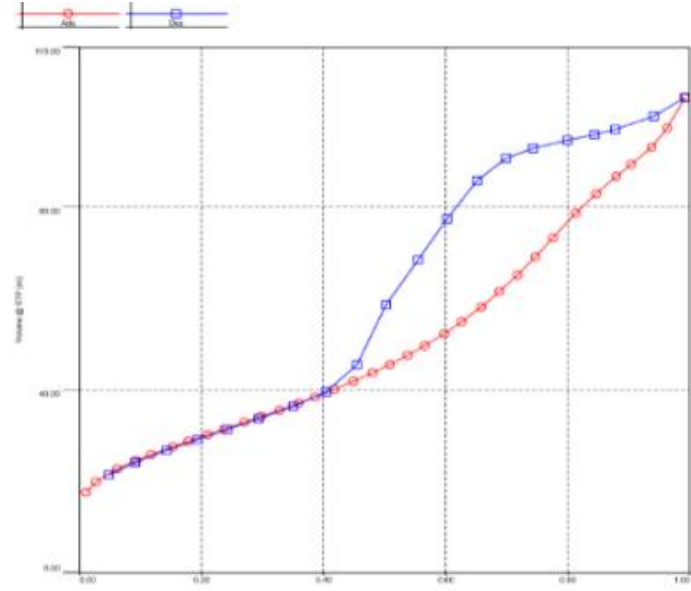

(a)

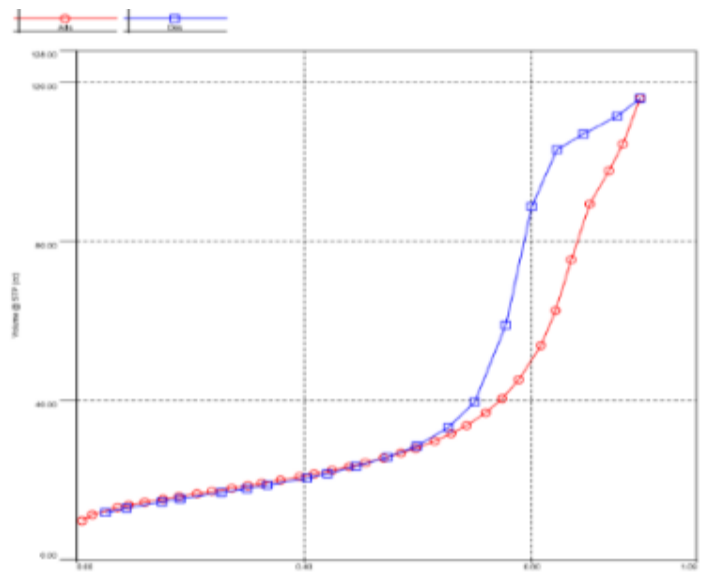

(c)

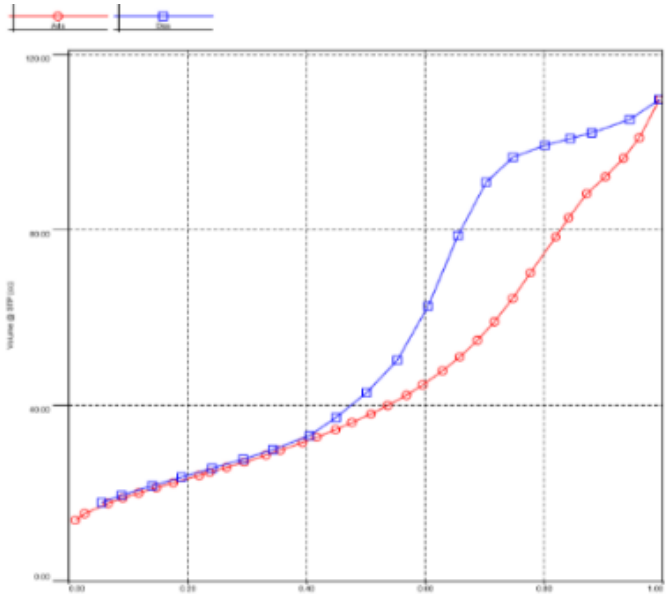

(b)

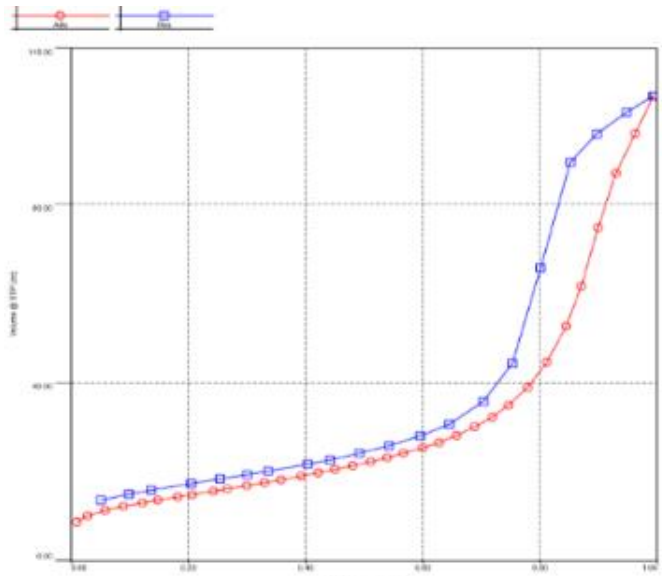

(d)

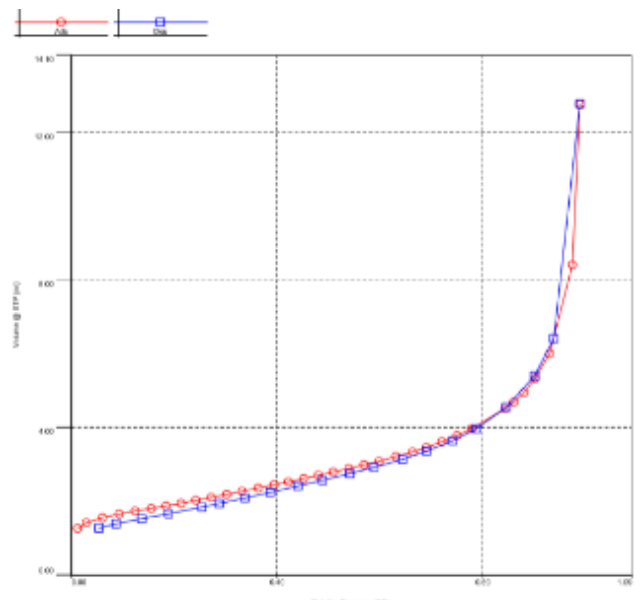

(e)

Figure 4. The isotherm curve of adsorption-desorption alumina (a) GA-500; (b) GA-650; (c) GA-800; (d) GA-950 dan (e) GA-1100

Based on the previous data, the GA-800 of gamma alumina retains a mesopore volume (pore volume at $P / P_{0}=0.99$ ) and the largest pore radius are $0.3265 \mathrm{~mL} / \mathrm{g}$ and $61.76 \AA$ respectively. Aside from specific surface area, those characteristics also influence surface adsorption, so that the particle size variations are carried out for this sample. To 
evaluate the particle size variations of $\mathrm{GA}$ 800 , it is used the ring mill and interval time of 2, 4 and 8 minutes. Three samples GA$800 / 1$ (size of $111.0 \mu \mathrm{m}$ ), GA-800/2 (size of $83.90 \mu \mathrm{m}$ ), and GA-800/3 (size of $15.65 \mu \mathrm{m}$ ) were characterized by PSA. The initial characterization was conducted by XRD. Figure 5 shows the XRD diffraction.

It can be seen from Figure 5 that the GA800/1 and GA-800/2 have a similar diffractogram of gamma alumina, but GA$800 / 3$ has a different diffractogram compared to the typical peak of gamma alumina and other sharp peaks. Therefore, refinement is needed to determine the alumina phase. The refinement result using the HighScore Plus program is shown in Table 8.
The refinement results confirm that the GA800/1 and GA-800/2 have a gamma alumina phase (100\%), while the GA-800/3 has both gamma alumina phase $(68.3 \%)$ and alpha alumina phase (31.7 \%). Particle size reduction into a nanoscale would decrease the temperature of sintering and calcination, so the particle size reduction to $15.65 \mu \mathrm{m}$, even though GA-800/3 particles were not counted as a nanomaterial, due to the alpha alumina phase with a proportion of $31.7 \%$ at a calcination temperature of $800{ }^{\circ} \mathrm{C}$. Meanwhile, the alpha alumina phase (100\%) which has a particle size of $111.0 \mu \mathrm{m}$ was formed at a calcination temperature of $1100{ }^{\circ} \mathrm{C}$ (GA1100). The next characterization of GA-800 with particle size variation was determined by surface area analyzer as shown in Table 9.

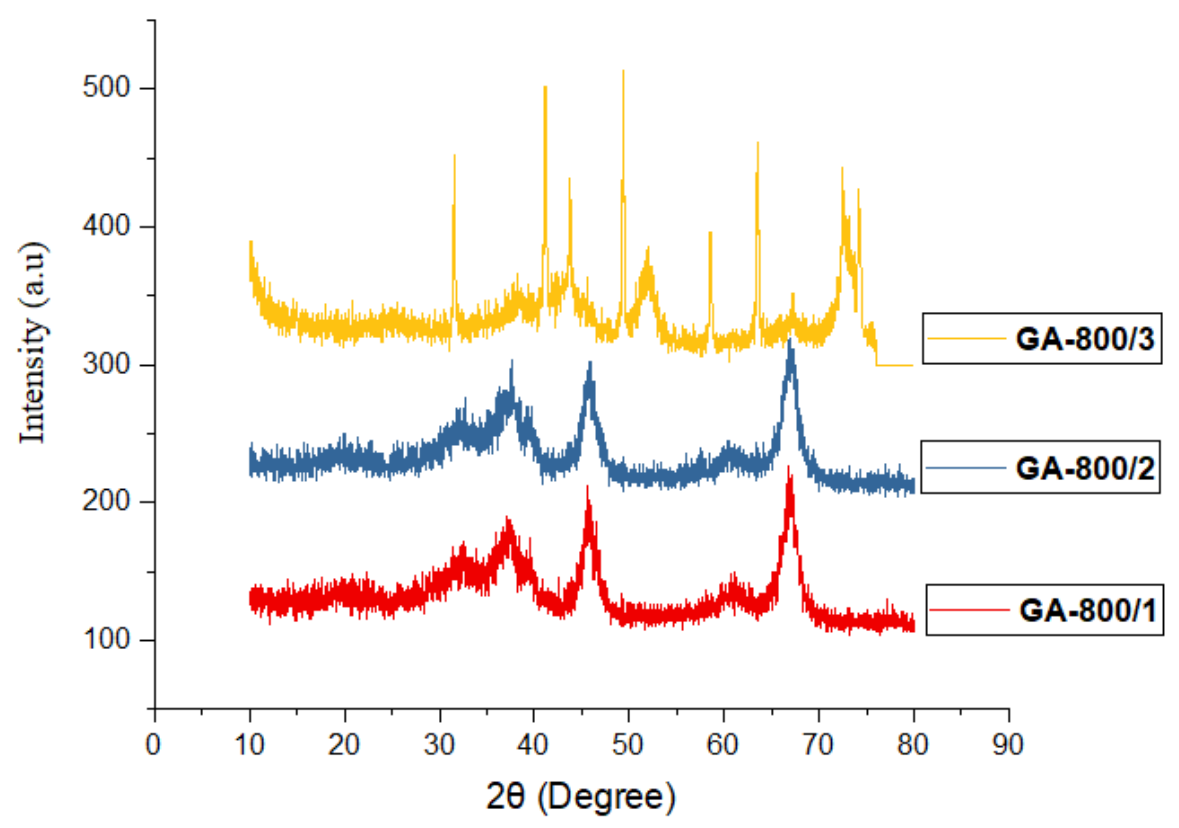

Figure 5. Results of XRD characterization of gamma alumina based on the particle size variation at the calcination temperature of $800^{\circ} \mathrm{C}$ : GA-800/1 (particle size $111.0 \mu \mathrm{m}$ ); GA-800/2 (particle size $83.90 \mu \mathrm{m}$ ) and GA-800/1 (particle size $15.65 \mu \mathrm{m}$ ).

Table 8. Refinement of GA-800 based on the particle size and used the HighScore Plus Program

\begin{tabular}{|c|c|c|c|}
\hline Sample & $\begin{array}{l}\text { Particle size } \\
(\mu \mathrm{m})\end{array}$ & $\begin{array}{l}\text { Alumina Phase } \\
(\%)\end{array}$ & GOF \\
\hline GA-800/1 & 111.0 & $\begin{array}{l}\text { Gamma alumina (100 \%) } \\
\text { standard ICSD 98-006-6559 }\end{array}$ & 1.70 \\
\hline GA-800/2 & 83.90 & $\begin{array}{l}\text { Gamma alumina }(100 \%) \\
\text { standard ICSD } 98-006-6559\end{array}$ & 1.64 \\
\hline GA-800/3 & 15.65 & $\begin{array}{l}\text { Gamma alumina (68,3 \%) standard ICSD 98-006-6559 Alpha } \\
\text { alumina }(31,7 \%) \text { standard ICSD 98-007-5559 }\end{array}$ & 1.48 \\
\hline
\end{tabular}


Synthesis and Characterization of Gamma Alumina and Its Adsorption ... Titin S. Fatimah et al.

Table 9. Characters of gamma alumina in 800-GA particles tested by surface area analyzer

\begin{tabular}{ccccccc}
\hline Sample & $\begin{array}{c}\text { Particle } \\
\text { size } \\
(\mu \mathrm{m})\end{array}$ & $\begin{array}{c}\text { Specific } \\
\text { surface area } \\
\mathrm{BET}\left(\mathrm{m}^{2} / \mathrm{g}\right)\end{array}$ & $\begin{array}{c}\text { Pore volume } \\
(\mathrm{mL} / \mathrm{g}) \\
\text { at } \mathrm{P} / \mathrm{P}_{0}=0,99\end{array}$ & $\begin{array}{c}\text { Micro pore } \\
\text { volume } \\
(\mathrm{mL} / \mathrm{g})\end{array}$ & $\begin{array}{c}\text { Total pore } \\
\text { volume } \\
(\mathrm{mL} / \mathrm{g})\end{array}$ & $\begin{array}{c}\text { Average } \\
\text { pore } \\
\text { radius }(\AA)\end{array}$ \\
\hline GA-800/1 & 111.0 & 105.725 & 0.3265 & 0.054 & 0.3805 & 61.76 \\
GA-800/2 & 83.90 & 110.281 & 0.3305 & 0.057 & 0.3875 & 59.94 \\
GA-800/3 & 15.65 & 104.119 & 0.2841 & 0.052 & 0.3361 & 54.58 \\
\hline
\end{tabular}

According to the data of $\mathrm{GA}-800 / 1$ and $\mathrm{GA}$ 800/2 shown in Table 9, reducing particle size will increase the specific surface area and total pore volume, while the pore radius decreases due to the smaller particle size. Meanwhile, GA-800/3 which was a mixture of gamma and alpha alumina phases had a smaller surface area and mesopore volume because of alpha alumina phase had low theoretical density and small cell volume.

SEM characterization was not carried out to all calcined samples because the XRD results in the range of $550-950{ }^{\circ} \mathrm{C}$ showed the same phase as gamma alumina, and one of them was GA-800. Another reason using the $800{ }^{\circ} \mathrm{C}$-calcination gamma alumina as a sample for SEM analysis was to determine the possible function of the gamma alumina other than that of an adsorbent, for example as a catalyst of $\mathrm{Ni} / \mathrm{Al}_{2} \mathrm{O}_{3}-\mathrm{MgO}$ in syngas production at 850 ${ }^{\circ} \mathrm{C}$. In addition, calcined gamma alumina at $800{ }^{\circ} \mathrm{C}$ has a greater total pore volume $(0.3265 \mathrm{~mL} / \mathrm{g})$ and pore radius of $61.76 \AA$ than other gamma alumina data. The larger pore radius and pore volume allow gamma alumina to adsorb more elements. The SEM results for GA-800 are shown in Figure 6.

Figure 6 shows the results of $800{ }^{\circ} \mathrm{C}$ calcination gamma alumina test using the secondary electron (SE) to produce a surface structure of the sample, gamma alumina in this study has a surface that is formed from the agglomeration of spherical sub-particles. According to Eliassi and Ranjbar (2014), the typical form of gamma alumina resulting from SEM characterization is called spherical and commercial gamma alumina. BASF alumina has indicated particle agglomeration with various sizes and a porous surface.

Figure 7 shows that the $\mathrm{GA}-800$ contains $\mathrm{Al}$ and $\mathrm{O}$, there are no other elements detected. It means that the produced gamma alumina is pure $\mathrm{Al}_{2} \mathrm{O}_{3}$ and free from the impurities.

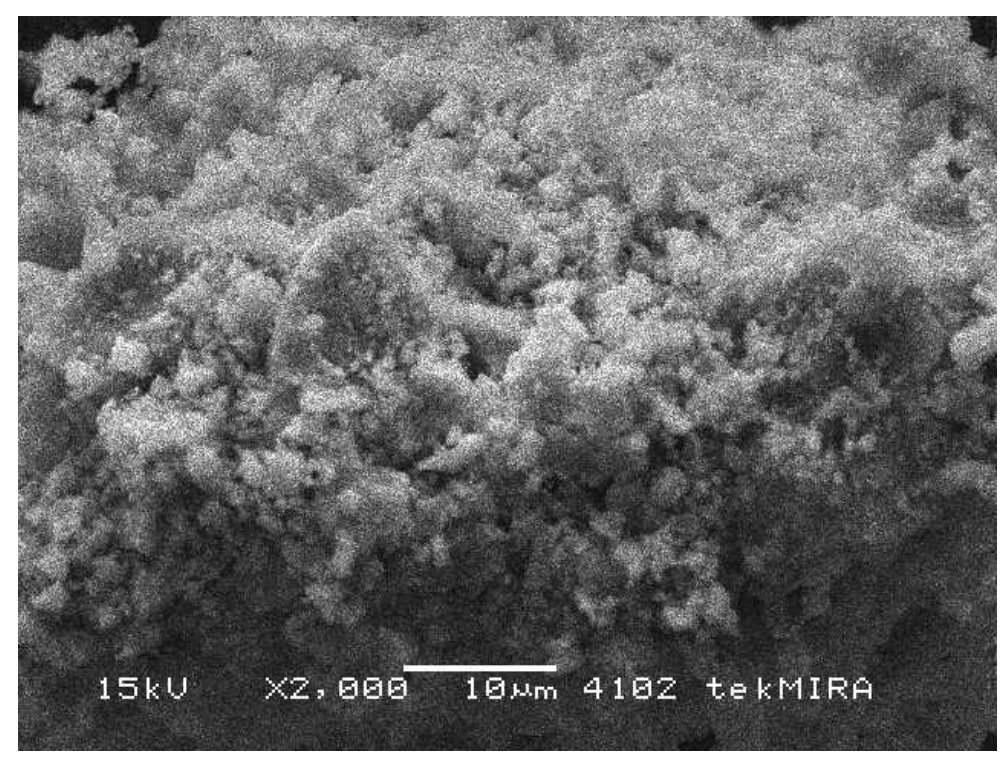

Figure 6. Photomicrograph of gamma alumina coded as GA-800 


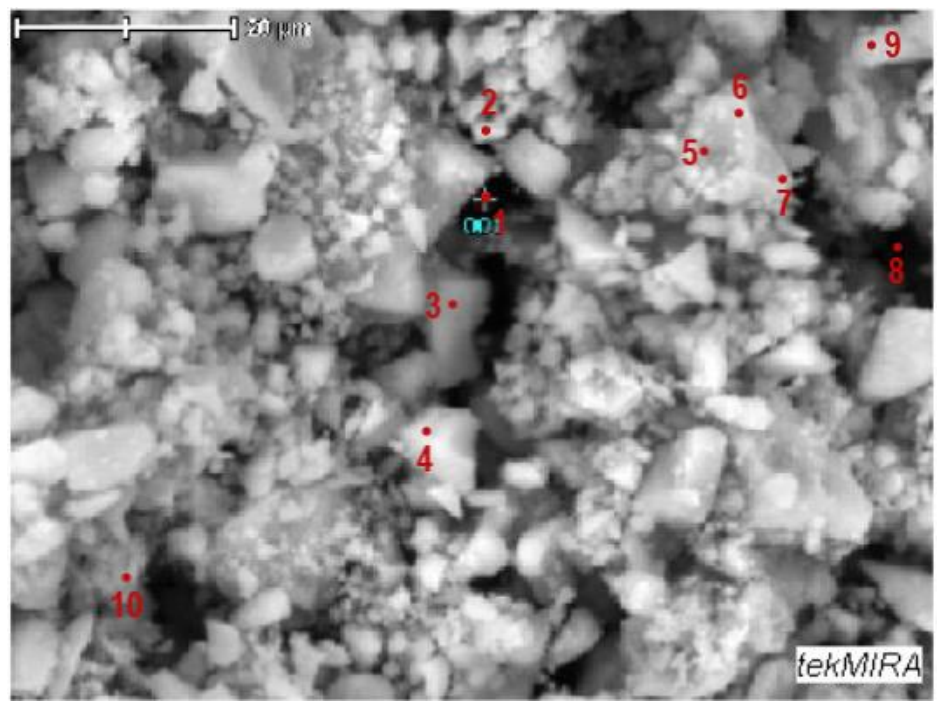

\begin{tabular}{cccccc}
\hline No. & element & Mass \% & Error \% & compound & Mass \% \\
\hline 1. & $\mathrm{O}$ & 47.07 & & & \\
& $\mathrm{Al}$ & 52.93 & 1.15 & $\mathrm{Al}_{2} \mathrm{O}_{3}$ & 100 \\
2. & $\mathrm{O}$ & 47.07 & & & \\
& $\mathrm{Al}$ & 52.93 & 1.22 & $\mathrm{Al}_{2} \mathrm{O}_{3}$ & 100 \\
3. & $\mathrm{O}$ & 47.07 & & & \\
& $\mathrm{Al}$ & 52.93 & 1.21 & $\mathrm{Al}_{2} \mathrm{O}_{3}$ & 100 \\
4. & $\mathrm{O}$ & 47.07 & & & \\
& $\mathrm{Al}$ & 52.93 & 1.22 & $\mathrm{Al}_{2} \mathrm{O}_{3}$ & 100 \\
5. & $\mathrm{O}$ & 47.07 & & & \\
& $\mathrm{Al}$ & 52.93 & 1.30 & $\mathrm{Al}_{2} \mathrm{O}_{3}$ & 100 \\
6. & $\mathrm{O}$ & 47.07 & & & \\
& $\mathrm{Al}$ & 52.93 & 1.23 & $\mathrm{Al}_{2} \mathrm{O}_{3}$ & 100 \\
7. & $\mathrm{O}$ & 47.07 & & & \\
& $\mathrm{Al}$ & 52.93 & 1.19 & $\mathrm{Al}_{2} \mathrm{O}_{3}$ & 100 \\
8. & $\mathrm{O}$ & 47.07 & & & \\
& $\mathrm{Al}$ & 52.93 & 1.28 & $\mathrm{Al}_{2} \mathrm{O}_{3}$ & 100 \\
9. & $\mathrm{O}$ & 47.07 & & & \\
& $\mathrm{Al}$ & 52.93 & 1.24 & $\mathrm{Al}_{2} \mathrm{O}_{3}$ & 100 \\
10. & $\mathrm{O}$ & 47.07 & & & \\
& $\mathrm{Al}$ & 52.93 & 1.18 & $\mathrm{Al}_{2} \mathrm{O}_{3}$ & 100 \\
\hline
\end{tabular}

Figure 7. Spot analysis of gamma alumina coded as GA-800; mag. 2500x; signal BSE.

\section{Magnesium Adsorption after Calcination}

AAS measurement of $\mathrm{Mg}$ concentration from the filtrate $\mathrm{pH}=10$ before and after adsorption are shown in Table 10. Based on Table 10, increasing calcination temperature from 500 to $1100{ }^{\circ} \mathrm{C}$ results in a greater concentration of $\mathrm{Mg}$ and $\mathrm{Ni}$ elements. It is expected to adsorb only the $\mathrm{Mg}$, but the $\mathrm{Ni}$ is also adsorbed due to its large concentration in the filtrate. The adsorption of $\mathrm{Ni}$ and $\mathrm{Mg}$ by gamma alumina when functioned as heterogeneous catalysts will be advantageous, such as $\mathrm{Ni} / \mathrm{Al}_{2} \mathrm{O}_{3}-\mathrm{MgO}$ catalyst for a syngas production (Aghamohammadi, Haghighi and Karimipouret, 2013). The adsorption capacities of alumina based on variations in calcination temperature are presented in Table 11.

Table 10. Composition of $\mathrm{Mg}$ and $\mathrm{Ni}$ within the filtrate $\mathrm{pH}=10$ before and after adsorption, particle size $111.0 \mu \mathrm{m}$

\begin{tabular}{lrc}
\hline \multicolumn{1}{c}{ Samples } & \multicolumn{1}{c}{$\mathrm{Mg}$} & \multicolumn{1}{c}{$\mathrm{Ni}$} \\
$(\mathrm{mg} / \mathrm{L})$ & $(\mathrm{mg} / \mathrm{L})$ \\
\hline Before adsorption & 229.73 & 22.71 \\
GA-500 & 73.46 & 16.37 \\
GA-650 & 79.38 & 18.27 \\
GA-800 & 89.52 & 19.33 \\
GA-950 & 125.20 & 20.45 \\
GA-1100 & 220.16 & 23.39 \\
\hline
\end{tabular}


Table 11. Adsorption capacities alumina, particle size $111.0 \mu \mathrm{m}$

\begin{tabular}{lcccc}
\hline \multirow{2}{*}{ Sample } & \multicolumn{2}{c}{ Adsorption } & \multicolumn{2}{c}{$\begin{array}{c}\text { Adsorption } \\
\text { capacities }\end{array}$} \\
\cline { 2 - 5 } & $\begin{array}{c}\mathrm{Mg} \\
(\mathrm{mg} / \mathrm{L})\end{array}$ & $\begin{array}{c}\mathrm{Ni} \\
(\mathrm{mg} / \mathrm{L})\end{array}$ & $\begin{array}{c}\mathrm{Mg} \\
(\mathrm{mg} / \mathrm{g})\end{array}$ & $\begin{array}{c}\mathrm{Ni} \\
(\mathrm{mg} / \mathrm{g})\end{array}$ \\
\hline GA-500 & 156.27 & 6.34 & 7.81 & 0.32 \\
GA-650 & 150.35 & 4.44 & 7.52 & 0.22 \\
GA-800 & 140.21 & 3.38 & 7.01 & 0.17 \\
GA-950 & 104.53 & 2.26 & 5.23 & 0.11 \\
GA-1100 & 9.58 & 0.68 & 0.49 & 0.034 \\
\hline
\end{tabular}

The adsorption abilities of GA-800/2 (83.90 $\mu \mathrm{m})$ and GA-800/3 (15.65 $\mu \mathrm{m})$ were determined by comparing the $\mathrm{Mg}$ and $\mathrm{Ni}$ filtrate concentrations before and after adsorption, which is shown in Table 12 and its adsorption capacity is presented in Table 13.

Table 12. The concentration of $\mathrm{Mg}$ and $\mathrm{Ni}$ filtrate $\mathrm{pH}=10$ before and after adsorption

\begin{tabular}{lcc}
\hline \multicolumn{1}{c}{ Sample } & $\mathrm{Mg}(\mathrm{mg} / \mathrm{L})$ & $\mathrm{Ni}(\mathrm{mg} / \mathrm{L})$ \\
\hline Before adsorption & 229.7333 & 22.7076 \\
GA-800/2 & 58.2196 & 19.2952 \\
GA-800/3 & 42.9481 & 20.5035 \\
\hline
\end{tabular}

Table 13 , indicated by GA- 800 and GA$800 / 2$ with $7.01 \mathrm{mg} / \mathrm{g}(61.03 \%)$ and 8.58 $\mathrm{mg} / \mathrm{g}(81.31 \%)$ respectively, shows the increase surface area of gamma alumina. However, the adsorption of magnesium by GA-800/3 (15.65 $\mu \mathrm{m})$ also increases while the nickel decreases. This is probably due to its lower particle size causes competition between the $\mathrm{Mg}$ and $\mathrm{Ni}$. The $\mathrm{Mg}$ content in the filtrate is greater than that of the $\mathrm{Ni}$. It is more likely that the $\mathrm{Mg}$ is absorbed. In addition, the adsorption condition at $\mathrm{pH}=10$ is also essential. Based on the interactions in terms of hard and soft acid and bases (HSAB), the surface of the gamma alumina at $\mathrm{pH}=10$ is negatively changed from $\mathrm{OH}^{-}$ (hard base) tends to react faster with $\mathrm{Mg}^{2+}$ (hard acids) rather than that of the $\mathrm{Ni}^{2+}$ (borderline acids), another possibility is that under the conditions of an excess alkaline solution, the $\mathrm{Mg}$ forms $\mathrm{Mg}^{2+}$ ions while $\mathrm{Ni}$ forms a complex solution $\left[\mathrm{Ni}\left(\mathrm{NH}_{3}\right)_{6}\right]^{2+}$, so that it will differ in its adsorption properties. The largest $\mathrm{Mg}$ adsorption capacity by gamma alumina occurred in GA-800/3 with the adsorption capacity of $9.34 \mathrm{mg} / \mathrm{g}(81.31$ $\%)$. The smaller the particle size, the bigger the surface energy. As a result, it makes the magnesium adsorption capacity becomes higher and the surface is more reactive.

Table 14 shows the specific surface area of GA-800/2 and GA-800/3 after adsorbing decreases from $110.281 \mathrm{~m}^{2} / \mathrm{g}$ to $104.40 \mathrm{~m}^{2} / \mathrm{g}$ and from $104,119 \mathrm{~m}^{2} / \mathrm{g}$ to $93.122 \mathrm{~m}^{2} / \mathrm{g}$ respectively. There is also a significant decrease of pore volume in mesoporous $\left(P / P_{0}=0.99\right)$, namely from $0.3305 \mathrm{~mL} / \mathrm{g}$ to $0.1835 \mathrm{~mL} / \mathrm{g}$ for $\mathrm{GA}-800 / 2$ and $0.2841 \mathrm{~mL} / \mathrm{g}$ to $0.1546 \mathrm{~mL} / \mathrm{g}$ for GA-800/3. No significant decline was seen in the microporous. Based on the pore volume data, the maximum adsorption occurred in mesopore volume. As a result, when making the adsorbents, it should be aware regarding the specific surface area and the mesopore volume. Reducing the pore volume affects the pore radius as indicated by its declining value from $59.94 \AA$ to $35.15 \AA$ for $\mathrm{GA}-800 / 2$ and $54.58 \AA$ to $33.21 \AA$ for $G A-800 / 3$ after adsorption.

After $\mathrm{Mg}$ and $\mathrm{Ni}$ adsorptions, the gamma alumina is characterized using XRD instruments to detect its diffractogram changes (Figure 8). The results show that a diffractogram is gamma alumina. No obvious changes are observed from the diffraction peaks. This implies that the $\mathrm{Mg}$ and $\mathrm{Ni}$ are dispersed evenly as small particles in the gamma alumina.

Table 13. The adsorption capacity of alumina with particle size variations

\begin{tabular}{lcccccc}
\hline \multicolumn{1}{c}{ Sample } & \multicolumn{2}{c}{ Adsorption } & \multicolumn{3}{c}{ Adsorption capacities } \\
\cline { 2 - 7 } & $\begin{array}{c}\mathrm{Mg} \\
(\mathrm{mg} / \mathrm{L})\end{array}$ & $\begin{array}{c}\mathrm{Ni} \\
(\mathrm{mg} / \mathrm{L})\end{array}$ & $\begin{array}{c}\mathrm{Mg} \\
(\mathrm{mg} / \mathrm{g})\end{array}$ & $\begin{array}{c}\mathrm{Mg} \\
(\%)\end{array}$ & $\begin{array}{c}\mathrm{Ni} \\
(\mathrm{mg} / \mathrm{g})\end{array}$ & $\begin{array}{c}\mathrm{Ni} \\
(\%)\end{array}$ \\
\hline $\begin{array}{l}\text { GA-800/2 } \\
\text { (particle size 83.90 } \mu \mathrm{m})\end{array}$ & 171.51 & 3.41 & 8.58 & 74.66 & 0.17 & 15.03 \\
$\begin{array}{l}\text { GA-800/3 } \\
\text { (particle size 15.65 } \mu \mathrm{m})\end{array}$ & 186.79 & 2.20 & 9.34 & 81.31 & 0.11 & 9.71 \\
\hline
\end{tabular}


Table 14. Characters of gamma alumina, tested by surface area analyzer on 800-GA particle size variation after adsorbing laterite filtrate $\mathrm{pH}=10$

\begin{tabular}{ccccccc}
\hline Sample & $\begin{array}{c}\text { Particle } \\
\text { size } \\
(\mu \mathrm{m})\end{array}$ & $\begin{array}{c}\text { Specific } \\
\text { surface area } \\
\text { BET }\left(\mathrm{m}^{2} / \mathrm{g}\right)\end{array}$ & $\begin{array}{c}\text { Pore volume } \\
(\mathrm{mL} / \mathrm{g}) \\
\text { at } \mathrm{P} / \mathrm{P}_{0}=0,99\end{array}$ & $\begin{array}{c}\text { Micro pore } \\
\text { volume } \\
(\mathrm{mL} / \mathrm{g})\end{array}$ & $\begin{array}{c}\text { Total pore } \\
\text { volume } \\
(\mathrm{mL} / \mathrm{g})\end{array}$ & $\begin{array}{c}\text { Average } \\
\text { pore } \\
\text { radius }(\AA)\end{array}$ \\
\hline $\mathrm{GA}-800 / 2$ & 83.90 & 104.40 & 0.1835 & 0.052 & 0.2355 & 35.15 \\
$\mathrm{GA}-800 / 3$ & 15.65 & 93.122 & 0.1546 & 0.047 & 0.2016 & 33.21 \\
\hline
\end{tabular}

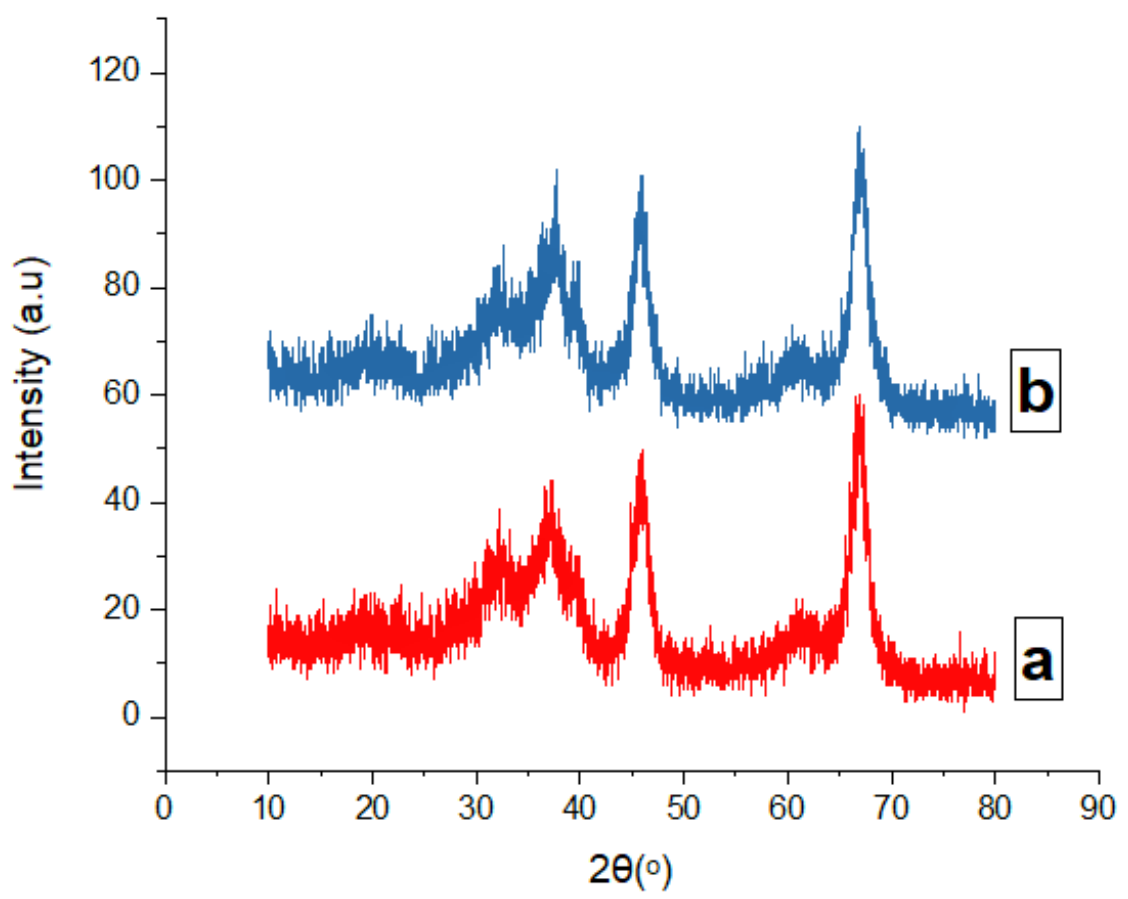

Figure 8. XRD analysis for gamma alumina GA-800, (a) before adsorption and (b) after adsorption

SEM-EDS tests were carried out to determine element distribution as a result of adsorption. The tested sample was GA-800. The results are shown in Figure 9.

Figure 9 shows that the gamma alumina has a composition similar to that of the AAS test consists namely of $\mathrm{Al}, \mathrm{Mg}$, and $\mathrm{Ni}$. The signal used in this spot analysis, namely backscattered electron, provides a difference in the molecular weight of the atoms within the specimen surface. The surface with high molecular weight will have a brighter image than those with the lower one. The results of the spot analysis show that the $\mathrm{Ni}$ retained the brighter image compared to that of the Al-Mg because such the $\mathrm{Ni}$ has a higher atomic weight than the $\mathrm{Al}$ and $\mathrm{Mg}$. The SEM X-ray mapping is also carried out to the sample of GA-800/2 after absorbing the $\mathrm{Mg}$, to determine the distribution of the elements between the adsorbent and the adsorbate. The results are shown in Figure 10.

The mapping characterization of the GA-800 shows that the sample consists of $\mathrm{Al}, \mathrm{Mg}$, and $\mathrm{Ni}$. The distribution of $\mathrm{Al}, \mathrm{O}$, and $\mathrm{Mg}$ has a similar in mapping pattern it, means that the $\mathrm{Mg}$ on the surface of the gamma alumina in this case of the $\mathrm{Al}$ and $\mathrm{Mg}$ take place in the same area.

From the results of the mapping, the largest mass percentage obtained as Al gamma alumina is $50.27 \%$, followed by $\mathrm{Mg}$ and $\mathrm{Ni}$ around $2.93 \%$ and $0.13 \%$ respectively. 


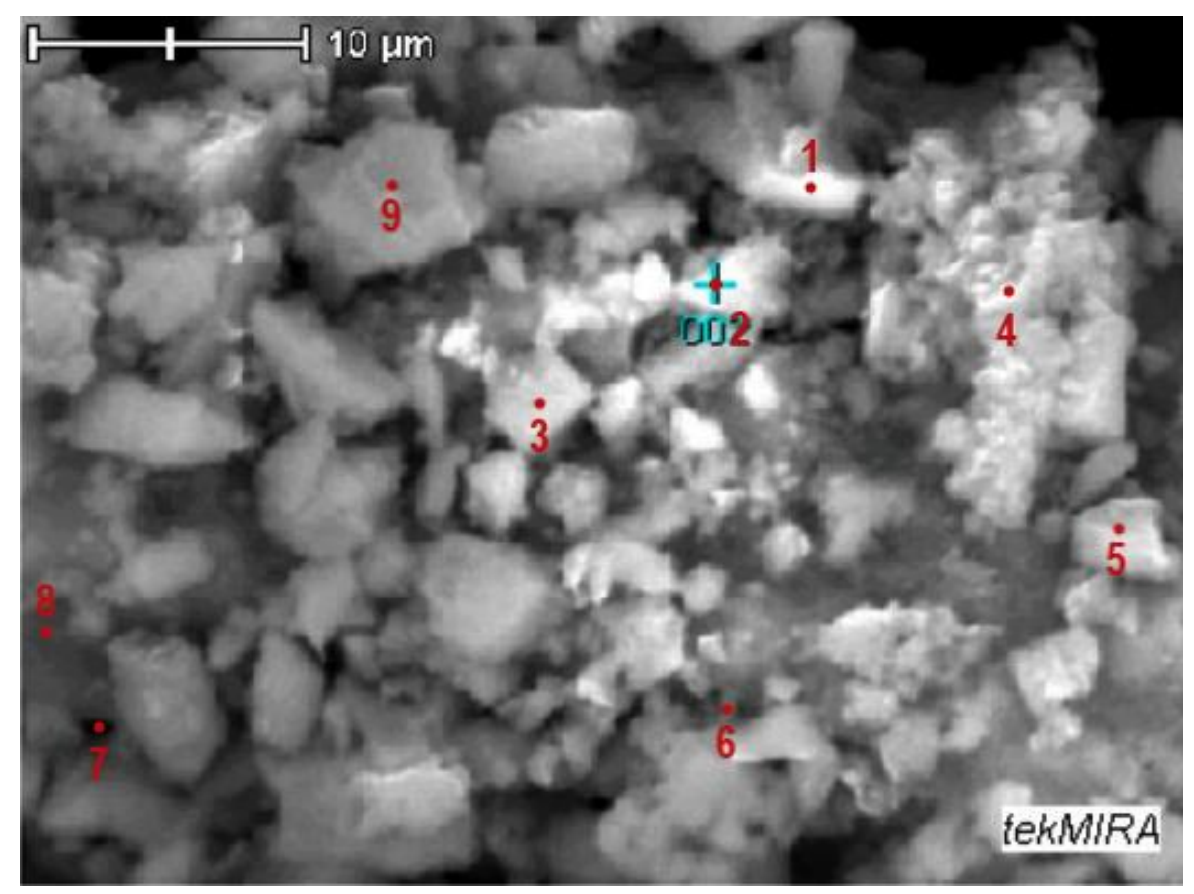

\begin{tabular}{|c|c|c|c|c|c|}
\hline No. & element & Mass \% & Error \% & compound & Mass \% \\
\hline \multirow[t]{4}{*}{1.} & 0 & 46.84 & - & - & - \\
\hline & $\mathrm{Mg}$ & 1.45 & 1.03 & $\mathrm{MgO}$ & 2.40 \\
\hline & Al & 51.54 & 1.10 & $\mathrm{Al}_{2} \mathrm{O}_{3}$ & 97.39 \\
\hline & $\mathrm{Ni}$ & 0.17 & 1.71 & $\mathrm{NiO}$ & 0.21 \\
\hline \multirow[t]{4}{*}{2.} & O & 46.82 & - & - & - \\
\hline & $\mathrm{Mg}$ & 1.67 & 1.06 & $\mathrm{MgO}$ & 2.91 \\
\hline & Al & 51.37 & 1.22 & $\mathrm{Al}_{2} \mathrm{O}_{3}$ & 96.95 \\
\hline & $\mathrm{Ni}$ & 0.14 & 1.03 & $\mathrm{NiO}$ & 0.24 \\
\hline \multirow[t]{3}{*}{3.} & 0 & 46.86 & - & - & - \\
\hline & $\mathrm{Mg}$ & 1.79 & 1.38 & $\mathrm{MgO}$ & 2.96 \\
\hline & $\mathrm{Al}$ & 51.36 & 1.17 & $\mathrm{Al}_{2} \mathrm{O}_{3}$ & 97.04 \\
\hline \multirow[t]{3}{*}{4.} & $\mathrm{O}$ & 46.78 & - & - & - \\
\hline & $\mathrm{Mg}$ & 2.38 & 1.55 & $\mathrm{MgO}$ & 3.94 \\
\hline & Al & 50.84 & 1.32 & $\mathrm{Al}_{2} \mathrm{O}_{3}$ & 96.06 \\
\hline \multirow[t]{3}{*}{5.} & 0 & 46.91 & - & - & - \\
\hline & $\mathrm{Mg}$ & 1.33 & 1.04 & $\mathrm{MgO}$ & 2.21 \\
\hline & Al & 51.76 & 1.20 & $\mathrm{Al}_{2} \mathrm{O}_{3}$ & 97.79 \\
\hline \multirow[t]{3}{*}{6.} & 0 & 46.90 & - & - & - \\
\hline & $\mathrm{Mq}$ & 1.45 & 1.02 & $\mathrm{MgO}$ & 2.41 \\
\hline & Al & 51.65 & 1.17 & $\mathrm{Al}_{2} \mathrm{O}_{3}$ & 97.59 \\
\hline \multirow[t]{3}{*}{7.} & 0 & 46.89 & - & - & - \\
\hline & $\mathrm{Mg}$ & 1.46 & 1.19 & $\mathrm{MgO}$ & 2.43 \\
\hline & $\mathrm{Al}$ & 51.64 & 1.37 & $\mathrm{Al}_{2} \mathrm{O}_{3}$ & 97.57 \\
\hline \multirow[t]{3}{*}{8.} & 0 & 46.93 & - & - & - \\
\hline & $\mathrm{Mg}$ & 1.18 & 1.32 & $\mathrm{MgO}$ & 1.96 \\
\hline & $\mathrm{Al}$ & 51.89 & 1.51 & $\mathrm{Al}_{2} \mathrm{O}_{3}$ & 98.04 \\
\hline \multirow[t]{3}{*}{9.} & 0 & 46.90 & - & - & - \\
\hline & $\mathrm{Mg}$ & 1.41 & 1.05 & $\mathrm{MgO}$ & 2.34 \\
\hline & Al & 51.69 & 1.20 & $\mathrm{Al}_{2} \mathrm{O}_{3}$ & 97.66 \\
\hline
\end{tabular}

Figure 9. SEM-EDS analysis for gamma alumina after Mg adsorption; mag. 2500x; signal BSE. 
INDONESIAN MINING JOURNAL Vol. 22, No. 1, April $2019: 1$ - 18
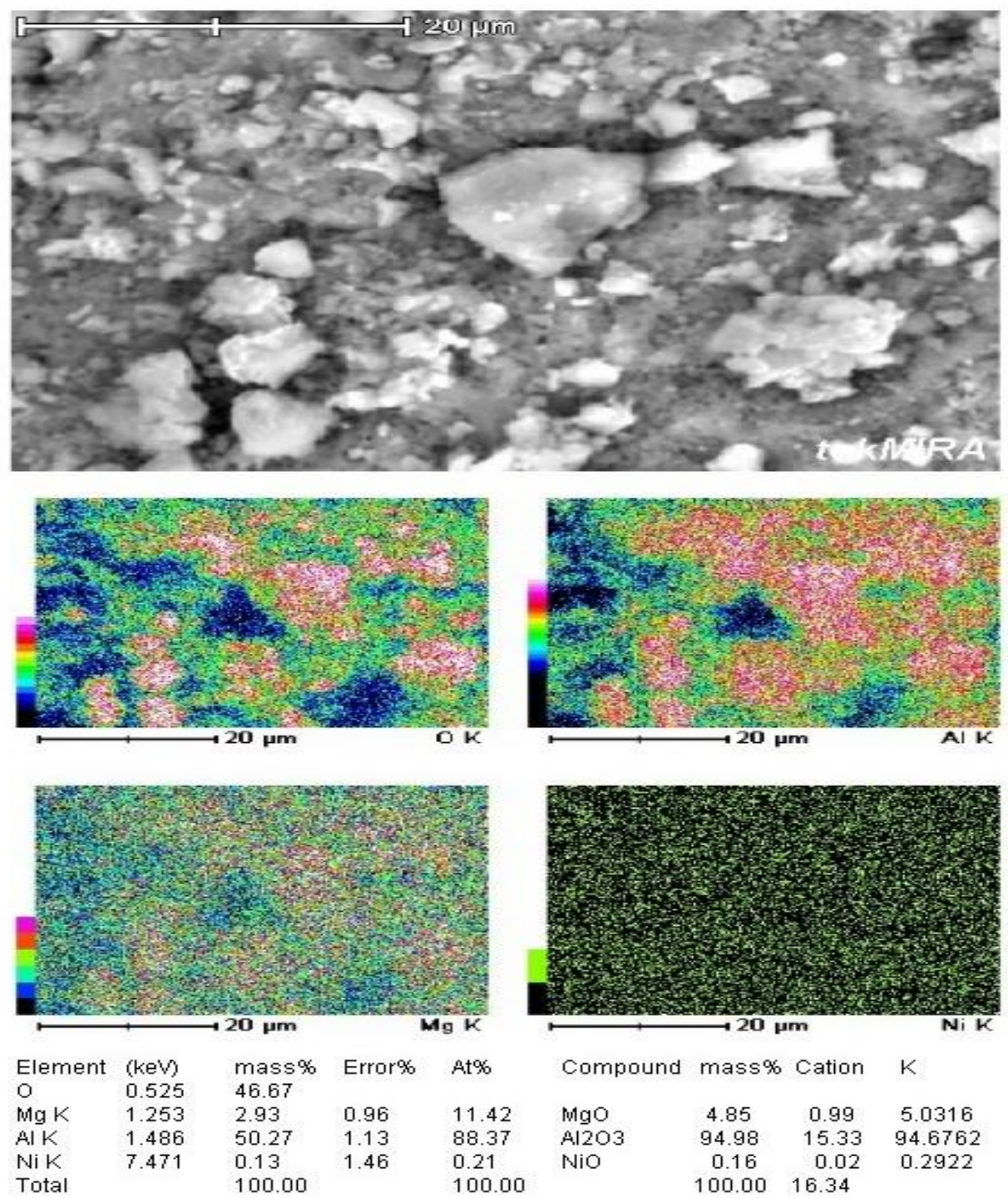

Compound mass $\%$ Cation $K$

$\begin{array}{lccc}\mathrm{MgO} & 4.85 & 0.99 & 5.0316 \\ \mathrm{Al} 2 \mathrm{O} 3 & 94.98 & 15.33 & 94.6762 \\ \mathrm{NiO} & 0.16 & 0.02 & 0.2922 \\ & 100.00 & 16.34 & \end{array}$

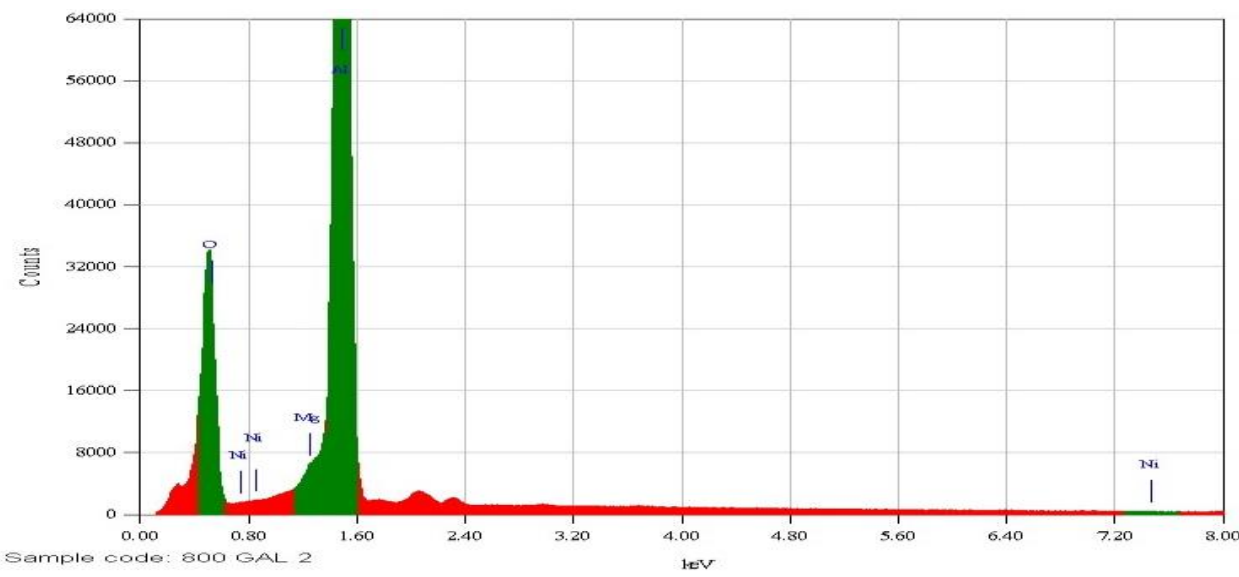

Figure 10. SEM mapping of gamma alumina after $\mathrm{Mg}$ adsorption for the sample coded as GA-800; Mag. 2500x; signal BSE 


\section{CONCLUSIONS}

Based on variations in calcination temperature, the gamma alumina has successfully been made using a simple solgel method. The XRD results show that the gamma alumina phase with particle size $111.0 \mu \mathrm{m}$ is available at $500,650,800$ and $950{ }^{\circ} \mathrm{C}$ while the alpha alumina phase is shown at $1100{ }^{\circ} \mathrm{C}$. The higher calcination temperature, the lower the specific surface area of gamma alumina. This results in decreasing the adsorption capacity. The magnesium from the laterite could be separated from the $\mathrm{Si}, \mathrm{Fe}$, and $\mathrm{Al}$, but the $\mathrm{Ni}$ remains as an impurity and was adsorbed.

Gamma alumina retains spherical surface in shape and has a type IV isotherm curve for mesoporous material. Spot and mapping analyses show that the gamma alumina is free from ammonium chloride $\left(\mathrm{NH}_{4} \mathrm{Cl}\right)$ impurities. In this study, the highest adsorption of $\mathrm{Mg}$ gamma alumina is around $81.31 \%$.

\section{ACKNOWLEDGEMENT}

The authors are very grateful to the Ministry of Energy and Mineral Resources of the Republic of Indonesia for financial support to conduct a gamma alumina research.

\section{REFERENCES}

Adamson, A. W. (1990) Physical chemistry of surfaces. 5th Ed. New York: Wiley.

Adans, Y. F., Martins, A. R., Coelho, R. E., Virgens, C. F. das, Ballarini, A. D. and Carvalho, L. S. (2016) 'A simple way to produce $y$-alumina from aluminum cans by precipitation reactions', Materials Research, 19(5), pp. 977-982. doi: 10.1590/1980-5373-MR-2016-0310.

Aghamohammadi, S., Haghighi, M. and Karimipouret, S. (2013) 'A comparative synthesis and physicochemical characterizations of $\mathrm{Ni} / \mathrm{Al} 2 \mathrm{O} 3-\mathrm{MgO}$ nanocatalyst via sequential impregnation and sol-gel methods used for CO2 reforming of methane', Journal of Nanoscience and Nanotechnology, 13(7), pp. 4872-4882. Available at: https://www.ncbi.nlm.nih.gov/pubmed/2 3901507\#.
Banerjee, S., Dubey, S., Gautam, R. K., Chattopadhyaya, M. C. and Sharma, Y. C. (2017) 'Adsorption characteristics of alumina nanoparticles for the removal of hazardous dye, Orange $G$ from aqueous solutions', Arabian Journal of Chemistry, p. (Inpress paper) 1. doi: 10.1016/j.arabjc.2016.12.016.

Bhatnagar, A., Kumar, E. and Sillanpää, M. (2010) 'Nitrate removal from water by nano-alumina: Characterization and sorption studies', Chemical Engineering Journal, 163(3), pp. 317-323. doi: 10.1016/j.cej.2010.08.008.

Butt, C. R. M. and Cluzel, D. (2013) 'Nickel laterite ore deposits: Weathered serpentinites', Elements, 9(2), pp. 123128. doi: 10.2113/gselements.9.2.123.

Chinnakoti, P., Chunduri, A. L. A., Vankayala, R. K., Patnaik, S. and Kamisetti, V. (2017) 'Enhanced fluoride adsorption by nano crystalline $Y$-alumina: adsorption kinetics, isotherm modeling and thermodynamic studies', Applied Water Science, 7(5), pp. 2413-2423. doi: 10.1007/s13201-016-0437-9.

Dahlan, Y., Pramusanto, Saleh, N., Ardha, I. G. N., Aziz, M., Amalia, D., Rodiyah, I., Setiyatmoko, E., Sarjono, Pendi, S., Somantri, S. and Sulistiani, L. (2007) Peningkatan kadar nikel dari bijih nikel laterit Pomalaa, Sulawesi Tenggara, Jurnal Teknologi Mineral dan Batubara. Bandung: Puslitbang tekMIRA.

Eliassi, A. and Ranjbar, M. (2014) 'Application of novel gamma alumina nano structure for preparation of dimethyl ether from methanol', International Journal of Nanoscience and Nanotechnology, 10(1), pp. 13-36. Available at: http://www.ijnnonline.net/article_5021.ht $\mathrm{ml}$.

Gulicovski, J. J., Čerović, L. S. and Milonjić, S. K. (2008) 'Point of zero charge and isoelectric point of alumina', Materials and Manufacturing Processes, 23(6), pp. 615-619. doi: $10.1080 / 10426910802160668$.

Harfani, R. (2009) Sintesis katalis padatan asam gamma alumina terfosfat $(\gamma$ Al2O3/PO4) dan digunakan untuk sintesis senyawa metil ester asam lemak dari limbah produksi margarin. Universitas Indonesia. Available at: http://lib.ui.ac.id/file?file=digital/2018187 4-S30537-Retno Harfani.pdf. 
Liu, K., Chen, Q. and Hu, H. (2009) 'Comparative leaching of minerals by sulphuric acid in a Chinese ferruginous nickel laterite ore', Hydrometallurgy, 98(3-4), pp. 281-286.

doi: 10.1016/j.hydromet.2009.05.015.

Luo, W., Feng, Q., Ou, L., Zhang, G. and Chen, Y. (2010) 'Kinetics of saprolitic laterite leaching by sulphuric acid at atmospheric pressure', Minerals Engineering, 23(6), pp. 458-462. doi: 10.1016/j.mineng.2009.10.006.

Mahmoudi, M. R. H., Kazemenini, M., Rashidi, A. M., Zarkesh, J. and Khorasheh, F. (2012) 'Comparison of regular gamma and nano structured alumina utilized in the Fischer Tropsch catalyst from porasimetric point of view', in Proceedings of the 4th international conference on nanostructure (ICNS4). Kish Island: Springer.

Márquez-Alvarez, C., Žilková, N., PérezPariente, J. and Čejka, J. (2008) 'Synthesis, characterization and catalytic applications of organized mesoporous aluminas', Catalysis Reviews, 50(2), pp. 222-286. doi: $10.1080 / 01614940701804042$.

Paglia, G., Buckley, C. E., Rohl, A. L., Hart, R. D., Winter, K., Studer, A. J., Hunter, B. A. and Hanna, J. V. (2004) 'Boehmite derived $\mathrm{y}$-alumina system. 1. Structural evolution with temperature, with the identification and structural determination of a new transition phase, Y'-alumina', Chemistry of Materials, 16(2), pp. 220-236. doi: $10.1021 / \mathrm{cm} 034917 \mathrm{j}$.

Poursani, A. S., Nilchi, A., Hassani, A. H., Shariat, M. and Nouri, J. (2015) 'A novel method for synthesis of nano- $y$ Al2O3: Study of adsorption behavior of chromium, nickel, cadmium and lead ions', International Journal of Environmental Science and Technology, 12(6), pp. 2003-2014. doi: 10.1007/s13762-014-0740-7.

Prasetyo, P. (2016) 'Sumber daya mineral di Indonesia khususnya bijih nikel laterit dan masalah pengolahannya sehubungan dengan UU Minerba 2009', in Prosiding SEMNASTEK 2016. Jakarta: Fakultas Teknik Universitas Muhammadiyah Jakarta, p. TM-008 110. Available at: https://jurnal.umj.ac.id/index.php/semna stek/article/view/807.

Shayesteh, M., Afarani, M. S., Samimi, A. and Khorram, M. (2013) 'Preparation of $y$ Al2O3 and prioritization of affecting factors on the crystallite size using Taguchi method', Transport Phenomena in Nano and Micro Scales, 1(1), pp. 45-52.

doi: 10.7508/TPNMS.2013.01.005 